\title{
CS-23 -El clima organizacional y la satisfacción laboral: estudio confirmatorio en el sector de las comunicaciones en Tabasco
}

\author{
Organizational climate and job satisfaction: confirmatory study in compa- \\ nies in the media of the state of Tabasco
}

María Concepción Frías Hernandez, Abel Pérez Sánchez*

Universidad Autónoma de Guadalajara Campus Tabasco, México

Autor a quien se dirige la correspondencia: abelperez2002@aol.comResumen

\section{Resumen}

E clima organizacional y la satisfacción laboral son dos fenómenos que relacionados influyen en la percepción de los colaboradores sobre el ambiente de trabajo y en el nivel de satisfacción laboral. El objetivo de este estudio fue confirmar la relación entre el clima organizacional y la satisfacción laboral. El estudio es de corte cuantitativo de tipo transversal utilizando el análisis factorial confirmatorio (AFC) mediante un sistema de ecuaciones estructurales SEM, por sus siglas en inglés, teniendo como muestra a colaboradores en empresas de los medios de comunicación del Estado de Tabasco, México, en donde se administraron 161 cuestionarios. Los resultados muestran que un incremento en una desviación estándar de clima organizacional impacta en 0.75 desviaciones estándar de satisfacción laboral y a la vez, un incremento en una desviación estándar de la satisfacción laboral impacta en 0.22 desviaciones estándar de clima organizacional, concluyendo que el clima organizacional tiene una relación directa y positiva con la satisfacción laboral.

Palabras claves: Clima organizacional, satisfacción laboral, medios de comunicación, actitudes, sistema de ecuaciones estructurales

\section{Abstract}

$\mathrm{O}$ rganizational climate and job satisfaction are two related phenomena that influence the perception of the collaborators on the work environment and the level of job satisfaction. The aim of this study was to confirm the relationship between organizational climate and job satisfaction. The quantitative study is transversal using confirmatory factor analysis (CFA) and structural equations system (SEM) having as partners in companies in the media of the State of Tabasco, Mexico, where 161 questionnaires were administered. The results show that an increase of one standard deviation of Organizational Climate affects 0.75 standard deviations of job satisfaction and in turn, an increase in the standard deviation of job satisfaction impacts 0.22 standard deviations of organizational climate, concluding that organizational climate has a direct and positive relationship with job satisfaction.

Key words: Organizational climate, job satisfaction, mass media, attitudes, structural equations model 